\title{
Republic of Turkey v. Christie's, Inc.
}

United States District Court, S.D. New York, Sep 7, 2021 - 17-cv-3086 (AJN)

\section{FINDINGS OF FACT AND CONCLUSIONS OF LAW}

\section{ALISON J. NATHAN, District Judge:}

The Republic of Turkey brings this case against Christie's and Michael Steinhardt, as well as the Idol-Defendant-in-rem Anatolian Marble Female Idol of Kiliya Type. This diversity action arises from the alleged unlawful excavation and smuggling out of Turkey of the Idol, a millennia-old cultural artifact that Turkey claims it owns pursuant to its patrimony law. The Idol ultimately made its way into the hands of Steinhardt, a private collector in the United States. The Second Amended Complaint alleges New York state law claims of conversion and replevin and seeks a declaratory judgment that all right, title, and interest in and to the Idol is vested in Turkey. Dkt. No. 65. Christie's and Steinhardt counterclaimed, alleging New York state law claims of tortious interference with contract, or, in the alternative, tortious interference with prospective economic advantage, and they seek a declaratory judgment that all right, title, and interest in and to the Idol is vested in Steinhardt. Dkt. No. 122. On September 30, 2019, the Court granted Turkey's motion for summary judgment on the Defendants' claims of tortious interference with contract and tortious interference with prospective economic advantage claims. Republic of Turkey v. Christie's Inc., 425 F. Supp. 3d 204, 218 (S.D.N.Y. 2019). Turkey's claims of conversion and replevin, and the parties' respective claims for a declaratory judgment, remained. Both sides' claims boil down to the question of who owns the Idol.

In April 2021, the Court conducted an eight-day bench trial on these claims. This Opinion and Order constitutes the Court's findings of fact and conclusions of law for purposes of Federal Rules of Civil Procedure 52(a)(2) and 65. To the extent any statement labeled as a finding of fact is a conclusion of law it shall be deemed a conclusion of law, and vice versa.

In sum, the Court finds and concludes that Turkey did not meet its burden of proof in establishing ownership of the Idol. Although the Idol was undoubtedly manufactured in what is now modern-day Turkey, the Court cannot conclude based on the trial record that it was excavated from Turkey after 1906, both prerequisites to a finding of ownership under the relevant law. The Court also finds and concludes that even if Turkey had established ownership, the trial record readily establishes that Turkey slept on its rights, which bars recovery under the doctrine of laches.
FINDINGS OF FACT

\section{Origins of the Idol}

The Idol was likely manufactured in the middle or late 5th millennium B.C.E., between 4800 and 4100 B.C.E, in Kulaksizlar, which is located in modern-day Turkey's Manisa Province in the region of Anatolia. Tr. 428:21-429:21 (Brodie); 832:24-834:2 (Anderson). The Idol belongs to the Kiliya figurine tradition, and Kulaksizlar is the only known manufacturing spot for Kiliya-type idols. Tr. 373:16-24 (Brodie); Tr. 837:4-13 (Anderson); PTX 284, Brodie Decl., ๆ 12; DTX 13A (Kulaçoğlu) at 77:19-25; DTX 201D, Anderson Decl., ๆ 29. Its size and near- mint condition make it among the most exceptional examples of Kiliya-type idols known to exist. Dkt. No. 307, Stipulated Fact No. 12

Where the Idol traveled to after its manufacture is more of a mystery. Idols of this kind were likely traded or exchanged. The known find-spots of other Kiliya-type idols supports this conclusion; one idol, for instance, was found in Kiliya, which is in the Gallipoli peninsula. Tr. 903:21-904:9 (Anderson). To date, no complete Kiliya-type idol has been found in Kulaksizlar. The exact reach of those trade or exchange networks, however, is unclear. Turkey argues that the trade networks were limited to nearby societies, relying primarily on the testimony of its expert witness, Dr. Neil Brodie. See PTX 284, Brodie Decl., ๆी 1215; Tr. 413:23-414:13, 431:6-14, 431:23-432:2, 417:11-22 (Brodie). The Defendants take a more expansive view. Their expert witness, Dr. Maxwell Anderson, points to evidence of Greek tools from the paleolithic period-around 5,000 years before the Chalcolithic period-found in Kulaksizlar as evidence that the trade networks reached, or could have reached, the islands of the Aegean Sea. Specifically, Dr. Anderson was discussing the findings of a 2018 report from excavations at Kulaksizlar, which mentioned "30 [Paleolithic] obsidian tools ... 27 of [which] were determined to have originated from the Greek island of Milos." DTX 61 at 2. The report also discusses the find in Kulaksizlar of a "miniature jadeite ax ...which could have originated from the island of Syros." Id. See also DTX 201D, Anderson Decl., I 34(c) (noting that the jadeite axe found at Kulaksizlar was traded concurrently with the date of the Idol). The 2018 Report concluded that "Kulaksizlar had an existence within the cultural interaction networks accepted to have been actively present during the Middle Chalcolithic Age." Id.

At a minimum, the evidence of these Greek tools in Kulaksizlar supports the proposition that it was technologically feasible for societies in the Aegean to trade with societies in Anatolia, including the Kulaksizlar region. But it is enough to say that there is insufficient evidence to support Turkey's view that the idols 
could not have been traded to the Aegean or to other regions outside of the boundaries of modern-day Turkey. On the contrary, the Court finds that such trade was feasible.

Kiliya-type idols continued to circulate in modern times, including before 1906. While Kiliya-type idols originated in Turkey, these idols have circulated outside of Turkey for at least 120 years. DTX 11A (Dinç) at 70:9-71:5. As proof of this, there are at least two Kiliya-type idols that were known to have existed outside of Anatolia prior to 1906. The first is currently in the Mytilene Museum on the Greek island of Lesbos. Tr. 899:20-900:14 (Anderson); PTX 266 ๆ 4. The second was found on the Gallipoli peninsula; that Kiliya-type idol was first published in 1902 and is today in Athens. PTX 266 ๆ 1; DTX 201D, Anderson Decl., ๆ 31. Those examples of Kiliya-type Idols that left Turkey prior to 1906 support the Defendants' position that the fact that the Idol was manufactured in Anatolia does not establish that the Idol remained in the boundaries of modern-day Turkey past 1906.

\section{The Idol's Ownership History}

The Idol emerged in New York in 1961, when J.J. Klejman, an art dealer, sold the Idol to Alastair and Edith Martin, prominent art collectors on the New York scene. See Dkt. No. 307, Stipulated Fact No. 5. The exact circumstances surrounding the trajectory of the Idol prior to 1961 are unclear. In part, this is because the Idol is unstratified - that is, its exact findspot and find date are unknown. There is no other direct evidence establishing even an approximate find spot and date or linking the Idol's excavation or discovery to anyone in particular. How Klejman came across the Idol is also a mystery. There is no evidence in the record to establish where he first encountered the Idol, how the Idol came to be in his possession, or when and how he brought the Idol to the United States. All that the Court can reasonably find is that in 1961, Klejman sold the Idol to the Martins.

The Martins owned the Idol for the next 22 years, and it formed a part of their renowned Guennol Collection. In 1983, they transferred the Idol to Buttercup Beta Corporation, owned by Alastair Martin's son, Robin Martin, and his children. Dkt. No. 307, Stipulated Fact No. 8. The Buttercup Beta Corporation was the Idol's owner for the next decade, until it sold the Idol to the Merrin Gallery on July 16, 1993. Dkt. No. 307, Stipulated Fact No. 9. Defendant Michael Steinhardt and his wife, Judy Steinhardt, then acquired the Idol from the Merrin Gallery on or around August 16, 1993. The Steinhardts have been the owners of the Idol since then. At trial, Mr. Steinhardt testified credibly about the circumstances surrounding his acquisition of the Idol. As he described, and as defense witness Samuel Merrin corroborated, Steinhardt spoke to a number of experts about the Idol prior to purchasing it, including Prudence Harper, Carlos Picon, and Joan Mertens. Tr. 614:1-12, 621:11-21 (Steinhardt); Tr. 493:7-9
(Merrin). He also testified that none of them raised any potential concerns about the provenance of the Idol, and that he trusted their expert opinion that the Idol was worth purchasing. ${ }^{1}$

In 2017, the Steinhardts attempted to sell the Idol. On March 1, 2017, Michael Steinhardt entered into an agreement with Christie's to consign the Idol to Christie's for sale by auction. For this purpose, Steinhardt agreed to appoint Christie's as his exclusive agent. Dkt. No. 307, Stipulated Fact No. 62. The next day, Steinhardt consigned the Idol to Christie's for sale, and the Idol was delivered to Christie's. Dkt. No. 307, Stipulated Fact No. 63. Christie's listed the Idol in the catalogue for its April 28, 2017 auction. Dkt. No. 307, Stipulated Fact No. 64. As a result of this litigation, prior to opening bidding on the Idol on April 28, 2017, Christie's read a statement explaining that Turkey had asserted a claim to the Idol; in doing so, Christie's noted that the buyer would have a right of cancellation if not satisfied with the terms of the sale. Dkt. No. 252 q 29. The Idol ultimately sold for a high bid of $\$ 12,700,000$. Id. $\uparrow 30$. The buyer, however, never took possession of the Idol, though the parties contest whether he ultimately "canceled the purchase," or "withdrew from consummating the sale." Id. ๆ $131-32$. As a result of this, the Idol remains in Christie's possession. Dkt. No. 252 I 2. See also Republic of Turkey v. Christie's Inc., 425 F. Supp. 3d 204, 209 (S.D.N.Y. 2019)

\section{Display and Publication History}

The Idol's prominence began to rise after the Martins acquired the Idol in 1961. In 1967, the Martins loaned the Idol to the Metropolitan Museum of Art for public display. The Idol was exhibited in the Met's permanent galleries from 1968 through 1993, with very few interruptions. Dkt. No. 307, Stipulated Fact No. 7; DTX 44 No. 5, 6, 8; DTX 54; DTX 55; see also DTX 102. As a result, the Idol was included in the Centennial Exhibition of the Guennol Collection in 1969-1970. DTX 54; DTX 55 at 6. Documents from the Met's archives indicate that during this period, the text of the gallery label for the Idol identified it as being Anatolian and a part of the Guennol Collection. DTX 59, 60, 121, 154; see also DTX 201A, Bernheimer Decl., ๆๆ 5-6; DTX 201D, Anderson Decl., I 36. After the Steinhardts acquired the Idol in 1993, the Idol was removed from the Met. In 1999, Steinhardt followed in the Martins' footsteps by loaning the Idol to the Met, where it was displayed until 2007. Stip. No. 24; DTX 44 No. 11; DTX 52, 57, 58;

\footnotetext{
1 Prior to trial, Turkey sought permission to introduce certain "other acts" evidence regarding the circumstances of Steinhardt's acquisitions of other antiquities. It did so under the theory that Steinhardt had a propensity for disregarding provenance when considering whether to purchase antiquities. In a pre-trial order, the Court denied Turkey's motion, concluding that Turkey's original theory of Steinhardt's allegedly unclean hands was precluded by the law of the case, which had already established that Steinhardt purchased the Idol in good faith. The Court also deemed the evidence irrelevant to Turkey's defense as to laches and impermissible under both Rule 404(b) and Rule 403. See Dkt. No. 417; see also Tr. 460:17-465:7. Having the benefit of presiding over the trial, the Court reaffirms its conclusion that such evidence would have been impermissible under Rule 401, Rule 403, and Rule 404(b).
} 
DTX 201BB, Steinhardt Decl., ๆ 28. During this time, the gallery label identified the Idol as Anatolian and specifically mentioned that it was on loan from the Judy and Michael Steinhardt Collection, New York. Dkt. No. 307, Stipulated Fact No. 24; DTX 44 No. 11; DTX 52, 57, 58; DTX 201BB, Steinhardt Decl., 9 28. In 2007, the Steinhardts retook possession of the Idol from the Met.

The decades of public display at the Met contributed to public awareness of the Idol's existence, but equally important was the history of publications discussing the Idol, identifying it as Anatolian and discussing its origins, referencing its place in the Guennol Collection, and indicating that it was located in the United States. The first of these was in 1964, when Herbert Hoffman published The Beauty of Ancient Art: Exhibition of the Norman Schimmel Collection. DTX 72. In 1974, Hoffman again mentioned the Idol in O.W. Muscarella's Ancient Art: The Norbert Schimmel Collection. DTX 73. In 1975, Elizabeth Rohde published an article that references the Idol. DTX 5 at 12; DTX 75A. Later, Prudence Harper, former curator in charge of the Met's Department of Ancient Near Eastern Art, published a two-volume work on the Guennol Collection that discusses the Idol and includes a photograph of it. DTX 77; DTX 201D, Anderson Decl., ๆ 64. Patricia Getz-Preziosi, a leading scholar of Neolithic and Chalcolithic statuettes, wrote an introduction for a publication in 1985 that references the Idol and includes an image. DTX 79. In 1986, Getz-Preziosi wrote a section of Martha Sharp Joukowsky's 1986 "Prehistoric Aphrodisias," which references the Idol and includes images of it. In 1990, Getz- Preziosi again referenced the Idol in a different publication. DTX 82.

Some of the publications had express ties to Turkey. Among the most notable publications that discussed the Idol is Jurgen Seeher's 1992 article, Anatolian Marble Statues of the Kiliya-Type. Seeher was in residence at the German Archaeological Institute in Istanbul at that time. DTX 44 No. 49. And in 2014, Önder Bilgi, an archaeology professor at Istanbul University, published a book, Anthropomorphic Representations in Anatolia, that names the Idol and features an image of it. DTX 189; DTX 201D, Anderson Decl., ๆ 50(e)(xiii).

Perhaps the most important public commentator on the Idol and its history was Özgen Acar, a prominent Turkish reporter considered to be one of the leading journalists on Turkish cultural heritage issues. Tr. 66:7-67:4 (Boz); DTX 11A (Dinç) at 29:314. Acar's 1989 article, History for Sale Again, published in Turkey in Cumhuriyet, a well-known newspaper, mentioned a Kiliyatype idol in the Guennol Collection. Dkt. No. 307, Stipulated Fact Nos. 29, 30; DTX 19A (Zoroğlu) at 226:11-13; DTX 81A. Acar had ties to Turkey's Ministry of Culture, having served at one point as consultant to former Minister of Culture Durmuş Fikri Sağlar, who served in the position in the 1990s. In 2017, Acar again wrote about the Idol after he learned that it was being auctioned at Christie's. DTX 63.

\section{Turkey's Awareness}

By the 1990s, awareness of the Idol in Turkey had reached new levels. In 1991, Rafet Dinç, a prominent specialist on Turkish antiquities, was working at the state-owned Manisa Museum when he learned about Kiliya-type idols. DTX 64A at n.1; DTX 219. In the early 1990s, Acar visited the Manisa Museum and showed Dinç photographs of Kiliya-type idols; Acar was the guest of the museum's director, and the director was present when Acar and Dinç discussed Kiliya-type idols. DTX 11A (Dinç) at 29:15-30:6. At around this time, Dinç read Seeher's article, which listed the Guennol Collection in New York as having a Kiliya-type idol. DTX 11A (Dinç) at 103:10-104:7. Dinç then left the museum to teach at a state-owned university in 1993, though he continued working with the Ministry of Culture on Kiliyatype idols. DTX 64A, 87-88.

Dinç continued researching Kiliya-type idols throughout the 1990s. In the early 1990s, he sought to excavate near Kulaksizlar; the Ministry of Culture only gave him permission to conduct a surface survey. After doing so, he reported to the Ministry that "Kiliya-type marble idols are of Anatolian origin and are spread in museums and private collections across the world." Stip. No. 57; PTX 283 19; DTX 11A (Dinç) at 176:11-18; DTX 64A, 158; DTX 201C 9 92. He presented his findings from the 1994 surface survey at a May 1995 symposium that was sponsored by the Ministry of Culture and at which employees of the Ministry were present. Stip. No. 56; DTX 44 No. 101; DTX 87B. In his presentation, Dinç discussed archaeological evidence he discovered in 1994 that Kulaksizlar was a marble workshop for the production of Kiliya-type idols. DTX 87B. The Ministry published Dinç's 1995 presentation the following year.

The Ministry then permitted Dinç to conduct another surface survey at Kulaksizlar in late 1995. Stip. Nos. 57, 58, 60; DTX 44 No. 122. Dinç presented his findings of the 1995 survey in May 1996 at a symposium in Ankara sponsored by the Ministry of Culture-again with Ministry employees present. Stip. No. 60; DTX 11A at 203:21-204:17; DTX 44 No. 125; DTX 65. That presentation included specific mention of the Idol. DTX 88A at 261. In 1997, the Ministry published Dinç's 1996 presentation. Id. at 261.

Also in 1997, the Ministry published Dinç's 1996 "Research Results" essay that identified a Kiliya-type idol in the Guennol Collection in New York. DTX 11A (Dinç) at 135:4- 138:5; DTX 44 No. 136; DTX $88 \mathrm{~A}$ at 261. As a general matter, the Ministry sends copies of the symposium publications to museums and archaeologists across Turkey. DTX 13A (Kulaçoğlu) at 18:17-19:10, 91:11-92:10; DTX 19A (Zoroğlu) at 52:22-53:10. The Ministry also published Dinç's 1997 essay, which identified the Idol as having been part of the Guennol Collection in New York, on its website. DTX 13A (Kulaçoğlu) at 59:22-61:3. 
In 2013, one scholar reported to the Office of the Director General that a Kiliya-type idol had been sold at Christie's in 2010; in doing so, he identified the Stargazer as having been part of the Guennol Collection and again reiterated that Kiliyatype idols abroad originated in Anatolia. See DTX 66. Leadership in the Ministry of Culture were made aware of that report. Tr. 88:25- 89:21 (Boz); DTX 19A (Zoroğlu) at 123:4-124:7; DTX 66.

\section{CONCLUSIONS OF LAW}

The parties agree that New York law applies to all substantive claims and affirmative defenses. See Dkt. No. 307, Stipulation of Law No. 2. And this Court has already concluded that under New York choice-of-law rules, Turkish law governs the question of whether Turkey has a property interest in the Idol. See Dkt. No. 285 at 5. But while the parties agree that Turkish law-and, in particular, the 1906 Decree-governs the question of whether Turkey has a property interest in the Idol, they dispute whether the 1906 Decree is enforceable.

The Court begins with the plain language of the decree. In determining whether foreign law vests ownership of antiquities in the state, courts must look first to the plain language of the relevant law. See United States v. Schultz, 333 F.3d 393, 399 (2d Cir. 2003) (analyzing Egyptian statute's text first). In this case, "the language of the [Decree] itself ... unequivocally asserts state ownership" of the Idol. See id. Article 4 of the 1906 Decree provides that

[a]ll monuments and immovable and movable antiquities situated in or on land and real estate belonging to the Government and to individuals and various communities, the existence of which is known or will hereafter become known, are the property of the Government of the Ottoman Empire. Consequently, the right to discover, preserve, collect and donate to museums the aforementioned belongs to the Government.

Dkt. No. 202-7 at 23. The Decree defines antiquity as "[a]ny work or any kind of product without exception, by any and all types of ancient peoples which once existed in or on the lands ruled by the Ottoman Government, related to fine arts, science, literature, religion and craft." Id. As this Court already concluded, under the plain terms of the decree, movable and immovable antiquities found on both public and private lands were "the property of the Government of the Ottoman Empire" during the time of its existence, and of modern-day Turkey thereafter. See Republic of Turkey v. Christie's Inc., 425 F. Supp. 3d 204, 215 (S.D.N.Y. 2019).. In its 2019 opinion, the Court acknowledged that the Defendants could offer evidence that the law is "not what its plain language indicates it is." Dkt. No. 468 at 37 (citing United States v. Schultz, 333 F.3d 393, 401-02 (2d Cir. 2003)). The Defendants have attempted to do so, relying on enforcement statistics, historical evidence regarding the existence of private ownership of antiquities, and an expert witness who testified that the law is not what it says it is. Dkt. No. 470 at $37-41$. Having considered the Defendants' arguments and evidence, however, the Court remains unpersuaded that the 1906 Decree means something other than what it says. The 1906 Decree is therefore an ownership law, and it controls the question of whether Turkey has an ownership claim to the Idol. As a result, Turkey prevails if it can establish extraction in modern day Turkey after 1906.

\section{Turkey has not established its entitlement to the Idol under the 1906 Decree}

To prevail on its claims for conversion and replevin, Turkey first bears the burden of establishing its rights, if any, to ownership of the Idol. Schoeps v. Museum of Modern Art, 594 F. Supp. 2d 461, 464 (S.D.N.Y. 2009). On a conversion claim, a plaintiff must establish (1) its "possessory right or interest in the property"; and (2) defendants' "dominion over the property or interference with it, in derogation of plaintiff's rights." Colavito v. N.Y. Organ Donor Network, Inc., 8 N.Y.3d 43, 50 (2006). In an action for replevin, the plaintiff "'must establish that the defendant is in possession of certain property of which the plaintiff claims to have a superior right."' Dore v. Wormley, 690 F. Supp. 2d 176, 183 (S.D.N.Y. 2010) (quoting Batsidis v. Batsidis, 778 N.Y.S. 2d 913, 913 (2d Dep't 2004)).

This Court has previously held, and the parties agree, that in order for Turkey to establish ownership under the 1906 Decree, it must prove by a preponderance of the evidence that the Idol was found within and exported from the boundaries of modern-day Turkey after 1906 while the Decree was in effect. Because the Court concludes that Turkey has failed to do so, Turkey cannot establish its entitlement to the Idol under the 1906 Decree.

\section{A. Location of the Idol}

The Court begins with where the Idol was found. Turkey advances a number of theories as to why it is entitled to an inference that the Idol was found in modern-day Turkey. Turkey first argues that the Court should assume that the Idol was found in modern-day Turkey because it originated in Anatolia. Dr. Neil Brodie, Turkey's expert witness, argues primarily that the evidence of the Anatolian origins of the Idol, combined with the evidence of the scope of the trade or exchange networks, supports the inference that the Idol was discovered or excavated in Anatolia. See PTX 284, Brodie Decl., ๆๆ 6, 12-21. The Court is unpersuaded. The mere fact that the Idol was manufactured in Anatolia is insufficient for Turkey to prove that the Idol was found in modern-day Turkey, thousands of years after the Idol was manufactured. Most notably, and as already noted, there is no direct evidence of the path that this particular Idol took after manufacture. Its location prior to 1961 is unknown. See PTX 284, Brodie Decl., ๆ 25; PTX 283, Boz Decl., ๆ 12. And Turkey's circumstantial evidence is unavailing, particularly in light of the fact that the Idols were circulated around the region after their manufacture. 
While the exact parameters of the Chalcolithic trade networks are unknown, Turkey's arguments that the trade networks did not extend beyond Anatolia are not founded in specific evidence. Turkey's expert witness, Dr. Neil Brodie, testified that there is no evidence that Kiliya-type Idols were traded beyond Anatolia, but Dr. Brodie's testimony was, at best, inconclusive. In addition, there is some evidence that there was trade between regions of what today constitute Greece and between Kulaksizlar-namely, certain Greek tools that were found in Kulaksizlar. Those tools were manufactured around 5,000 years before the date of the Idol's production-in the paleolithic period. Tr. 414:5-13. Dr. Brodie testified that the presence of those tools could not "tell you anything about trade and exchange" of the Idol. Tr. 431:23-432:2. But even if the specific relevance of the paleolithic tools is somewhat limited in this context, they prove, at a minimum, that trade networks had existed that connected Anatolia to the land that today constitutes Greece. In that regard, the Court is unpersuaded by Dr. Brodie's expert testimony that the Idol's manufacture in Anatolia, combined with what is known of the trade networks during the Chalcolithic period, is sufficient to infer the Idol's discovery in modern-day Turkey. In contrast, the Court was persuaded by Dr. Maxwell Anderson's testimony that trade and travel during that period could have reached the Aegean. Tr. 866:3-14, 870:15- 873:2 (Anderson).

In addition, the Defendants presented evidence that Kiliyatype idols have also been circulated in modern times, including before 1906. One scholar testified that these idols have circulated outside of Turkey for at least 120 years. DTX 11A (Dinç) at 70:9-71:5. In 1994, one Turkish professor wrote to a Turkish official that Kiliya-type idols had circulated outside of Turkey for 120 years. DTX 219. Indeed, there are at least two Kiliya-type idols that were known to have existed outside of Anatolia prior to 1906. The first is currently in the Mytilene Museum on the Greek island of Lesbos. Dr. Anderson testified that the Idol was likely acquired before 1865. Tr. 899:20-900:14 (Anderson); PTX 266 I 4. The second was found on the Gallipoli peninsula; that Kiliya-type idol was first published in 1902 and is today in Athens. PTX 266 9 1; DTX 201D, Anderson Decl., १ 31. Taken together, this evidence establishes that the Idols were transported both during the Chalcolithic period and in the 19th and early 20th centuries. Thus, on this record, the mere fact that the Idol was manufactured in Kulaksizlar is insufficient to warrant an inference that the Idol was found in modern-day Turkey.

Nor does JJ Klejman's role in bringing the Idol to the United States support Turkey's contention that a preponderance of the evidence proves the Idol's discovery in modern-day Turkey. Dr. Brodie testified that Klejman was "a primary conduit into the United States for material looted from Turkey and the Middle East." PTX 284, Brodie Decl., I 20. Brodie based this opinion on the memoir of Thomas Hoving. Id.; see also PTX 66. And while Klejman was involved in bringing the Lydian Hoard to the United States, Brodie's testimony proves too much; Hoving's memoir does not reveal much about Klejman's specific trading practices, whether as it relates to Turkey or any other country that was beset by looting in the 19th and 20th centuries. So the Court gives little credit to Brodie's testimony that Klejman's involvement provides support for the fact that the Idol was found in modern-day Turkey.

For these reasons, the Court is unpersuaded by Turkey's contention that it is entitled to an inference on this trial record that the Idol was found in modern-day Turkey. Turkey did not carry its burden of proving by a preponderance of the evidence that the Idol was found in modern-day Turkey.

\section{B. Date of Discovery}

The precise date of the Idol's discovery, excavation, or export is unknown. There is no evidence of the excavation or exportincluding photographs and testimony of direct witnesses. See DTX 10A (Bozkurtlar) at 125:25-126:18; DTX 17A (Talaakar) at 79:19-80:6; DTX 19A (Zoroğlu) at 254:6-12; DTX 201D, Anderson Decl., ๆ 75. And it is uncontested that at least two Kiliya-type idols were excavated before 1906. Tr. 899:20-900:14 (Anderson); PTX 266 ๆा 1, 4; DTX 201D, Anderson Decl., ๆ 31. Unlike in those examples, there is no direct evidence of when this Idol was found. So as above, in the absence of direct evidence Turkey relies on circumstantial evidence to establish that the Idol was excavated or discovered after 1906. The Court was not persuaded.

Turkey contends that the Court should infer that the Idol's discovery and export occurred after 1906 because the Idol first appeared in 1961 and stolen or looted antiquities often arrive quickly on the market. See Dkt. No. 468 १ๆ 119, 121, 123. In doing so, it relies largely on the testimony of Dr. Brodie, who testified that the Idol would have been well-known had it been discovered before 1961. Id. Perhaps, but the Court was persuaded by the testimony of Dr. Anderson, the Defendants' expert witness, who testified that there are numerous reasons of why an object might not surface immediately after its discovery. DTX 201D, Anderson Decl., ๆ 35. The Court need not exhaust the universe of possibilities, however, because the mere fact that the Idol surfaced in 1961 is plainly insufficient to establish that the Idol must have been found after 1906. Indeed, of the two Idols that are known to have been excavated prior to 1906, neither generated significant attention among scholars or collectors of antiquities. See PTX 266 १ी 1, 4. It is therefore just as possible that the Idol was discovered prior to 1906 but did not attract much attention until decades later, when it found its way to JJ Klejman. Yet again, the dearth of direct evidence and the weakness of circumstantial evidence precludes Turkey's satisfaction of its burden. Turkey did not establish by a preponderance of the evidence that the Idol was discovered, excavated, or exported after 1906, when the decree was in effect.

In sum, Turkey bears the burden of proof of establishing by a preponderance of the evidence that it has an ownership claim to the Idol. In order to prevail, Turkey would have to show that the Idol was excavated within the boundaries of modern-day Turkey sometime after 1906. Having carefully considered the 
substantial trial record, the Court concludes that Turkey has not satisfied its burden. In light of this, Turkey's claims for conversion and replevin fail.

\section{Defendants' laches defense bars Turkey's claims}

Even if Turkey had established its claim of ownership over the Idol, the Court would still rule that the doctrine of laches bars Turkey's claim over the Idol. The equitable defense of laches is governed by New York law. Dkt. No. 307, Stipulation of Law No. 2; Bakalar v. Vavra, 819 F. Supp. 2d 293, 303 (S.D.N.Y. 2011), aff'd, 500 F. App'x 6 (2d Cir. 2012). To prevail on their laches defense, Defendants must show that Turkey "inexcusably slept on its rights so as to make a decree against the defendant unfair. Laches ... requires a showing by the defendant that it has been prejudiced by the plaintiff's unreasonable delay in bringing the action." Zuckerman v. Metropolitan Museum of Art, 928 F.3d 186, 193 (2d Cir. 2019) (citation omitted). See also Bakalar, 819 F. Supp. 2 d at 203 ("In order to prove laches, [Defendants] must show that: (1) [Plaintiff was] aware of [its] claim, (2) [Plaintiff] inexcusably delayed in taking action; and (3) [Defendants were] prejudiced as a result." (citation omitted)). It is enough, under New York law, that a party "should have known" of its claim. Bakalar, 819 F. Supp. 2d at 303 (citations omitted) (emphasis added). In conducting the laches analysis, courts take into account both parties' diligence. Solomon R. Guggenheim Found. v. Lubell, 550 N.Y.S. 2d 618, 623 (App. Div. 1990) ("defendant's vigilance is as much in issue as plaintiff's diligence. ... The reasonableness of both parties must be considered and weighed.").

\section{A. Turkey's awareness}

For purposes of the doctrine of laches, the Defendants need only prove that Turkey knew of, or should have known of, the circumstances giving rise to the claim, even if it could not ascertain the current possessor of the object in question. Bakalar, 819 F. Supp. 2d at 304 (citation omitted). In conducting this kind of analysis, it is relevant that the missing object was widely discussed in the literature or put in public display, particularly when the object in question is well-known. See Zuckerman, 928 F.3d at 192-194 (finding that delay was unreasonable where the painting, a "masterwork" by Picasso that was "not an obscure piece of art," was on display at the Met, "a major public institution," and had been "published in the [museum's] published catalogue of French paintings" since 1967); see also Matter of Peters v. Sotheby's Inc., 821 N.Y.S. 2d 61, 68-69 (1st Dep't 2006) (concluding that a failure to make a demand for the painting at issue was unreasonable where "the painting was exhibited as part of the [owner's] collection at prominent museums, galleries, and universities").

The Court need not determine the precise date on which Turkey knew of its claim because it concludes that Turkey should have known of its claim decades before 2017, when it finally initiated its attempt to recover the Idol. As discussed above, the
Idol was widely discussed in the literature starting in the 1960s, and it was in near-constant display at the Metropolitan Museum of Art for decades. The Court will not recount the entire publication and display history, but it finds especially relevant to the Defendants' laches defense that as early as the 1980s and early 1990s—before Steinhardt even bought the Idol-the Idol was discussed in Turkish publications by academics with connections to the Ministry of Culture. Dinç was working in a state-owned museum when he learned about Kiliya-type idols in 1991, and he was made aware of Seeher's article, which listed the Idol as belonging to the Guennol Collection in New York, in the early 1990s. DTX 11A (Dinç) at 103:10-104:7. In the 1990s, Dinç reported to the Ministry "Kiliya-type marble idols are of Anatolian origin and are spread in museums and private collections across the world." Stip. No. 57; PTX 283 १ 9; DTX 11A (Dinç) at 176:11-18; DTX 64A, 158; DTX 201C 192 . And he twice presented his findings in events sponsored by the Ministry of Culture, which published both presentations. Indeed, in 1997, the Ministry published Dinç's 1996 "Research Results" essay that identified a Kiliya-type idol in the Guennol Collection. DTX 11A (Dinç) at 135:4-138:5; DTX 44 No. 136; DTX 88A at 261. As noted above, the Ministry also published Dinç's 1997 essay, which identified the Idol as having been part of the Guennol Collection in New York, on its website. DTX 13A (Kulaçoğlu) at 59:22- 61:3.

Turkey argues that even if there is evidence regarding its awareness of the existence of the Idol, the evidence would not support the proposition that Turkey was, or should have been, aware of any potential claim it could assert to recover the Idol. The Court is unpersuaded. As a preliminary matter, Turkey claims ownership over all objects found in Turkey. See Republic of Turkey v. Metro. Museum of Art, 762 F. Supp. 44, 45-47 (S.D.N.Y. 1990). The Idol has universally been described as Anatolian in the literature and in its display history. Awareness of the existence of the Idol, should have put Turkey on notice as to its potential claim - at least enough to inquire further. Notwithstanding the prominence of the Idol, however, Turkey took no steps to ascertain whether it was entitled to ownership over the object despite being aware of its existence for decades.

Nor is the Court persuaded by Turkey's argument that it cannot be expected to inquire as to any objects around the world that are described as being of Anatolian origin. See Dkt. No. 471 at 17-18. The Court agrees that such an expectation would be unreasonable, but it finds that the specific facts of this case do not compel such a broad conclusion regarding when Turkey is expected to inquire as to a potential claim. Here, there is evidence that government officials were made aware of this specific Idol as early as the 1990s, in contexts that described the Idol as being of Anatolian origin. Thus, the point is certainly not that Turkey has an obligation to seek out or inquire all artefacts described as being of Anatolian origin. Rather, the narrower conclusion is that on the facts of this case, where there is evidence that Turkey was presented with information that the Idol was of Anatolian origin and that the Idol was historically significant, and that only then did Turkey have a duty either to 
inquire further or to risk facing a laches defense if it initiated an enforcement action in the future. Altogether, the Defendants have satisfied their burden of showing that Turkey should have known of the circumstances giving rise to its claim significantly earlier than 2017. See Bakalar, 819 F. Supp. 2 d at 304.

\section{B. Inexcusable delay}

It is undisputed that Turkey took no action with respect to the Idol until shortly before initiating this action. The knowledge prong of the laches analysis is intertwined with the scope of required diligence, as any potential claimant must act reasonably on the basis of any information it possesses or should possess. Bakalar, 819 F. Supp. 2d at 304. As already noted, the Court concludes that the evidence shows that Turkey was, or should have been aware, of the existence of the Idol, of its historical significance, of its Anatolian origins, and of its location in New York by the 1990s, if not sooner. So the relevant question, for purposes of assessing the strength of the Defendants' laches defense, is whether Turkey inexcusably delayed in taking action. The Court concludes that it did.

Relevant here is the fact that Turkey failed to take any steps to even inquire as to the origins of the Idol, how it made its way to New York, and whether it had any potential claim. Such a failure to inquire or investigate is probative of inexcusable delay, even when the precise elements of a potential claim-including the unlawful possessor of the object-are unknown. See, e.g., Sanchez v. Trs. of the Univ. of Pa., No. 04-cv-1253 (JSR), 2005 U.S. Dist. LEXIS 636, at *8 (S.D.N.Y. Jan. 13, 2005); Greek Orthodox Patriarchate v. Christie's, Inc., No. 98-cv-7664 (KMW), 1999 U.S. Dist. LEXIS 13257, at *23-31 (S.D.N.Y. Aug. 18, 1999). Turkey's expert witness was unable to identify any step that Turkey took to inquire or investigate in the decades following the dissemination of information in Turkey regarding the Idol and the start of this action. See Tr. 368:6-20 (Brodie). The Court finds it especially relevant that Turkey was, or should have been aware, that the Idol was on display at the Metropolitan Museum of Art. As the Second Circuit has observed, the Met is a "major public institution," Zuckerman, 928 F.3d at 194, and the Met did not hide that the Idol was part of the Guennol Collection. Turkey failed to contact the Met seeking more information about the origins of the Idol-a relatively low bar, all things considered, and one that Turkey should reasonably have surpassed.

Thus, the Court concludes that Turkey inexcusably delayed in taking action and finds that this element of the analysis also supports a finding of laches. At a minimum, Turkey should have inquired once it knew that the Idol was of Anatolian origin, that it was historically significant, and that it was located in New York.

\section{Prejudice}

The third element of a laches defense is that the moving party was prejudiced as a result of the opposing party's unreasonable delay. Zuckerman, 928 F.3d at 194. "A defendant has been prejudiced by a delay when the assertion of a claim available some time ago would be inequitable in light of the delay in bringing that claim." Conopco Inc. v. Campbell Soup Co., 95 F.3d 187, 192 (2d Cir. 1996). When assessing prejudice, courts consider "the decreased ability of the defendants to vindicate themselves, on account of the death of witnesses or fading memories and stale evidence, as well as the prejudice that may result from a change in the defendant's position." Merchant v. Lymon, 828 F. Supp. 1048, 1063 (S.D.N.Y. 1993). In Zuckerman, for instance, the Second Circuit concluded that the Met was prejudiced as a result of "'deceased witness[es], faded memories, ... and hearsay testimony of questionable value,' as well as the likely disappearance of documentary evidence." Zuckerman, 928 F.3d at 194 (quoting Lubell, 153 A.D. 2d at 149).

The Defendants' ability to mount a defense was unquestionably impacted by the death of potential witnesses and the loss of documentary evidence. For instance, the Defendants were unable to seek out evidence regarding how the Martins came to possess the Idol, including the circumstances in which JJ Klejman came across the Idol. By the time this action was initiated, Alastair Martin, Edith Martin, and JJ Klejman had all died. As a result, the Defendants were hampered in their ability to marshal evidence that could rebut Turkey's theory of the circumstances leading up to the Idol's transport to the United States. For instance, Klejman could have testified that he acquired the Idol somewhere outside of Turkey, circumstantial evidence that would support the Defendants' claim that the Idol was not discovered or excavated in Turkey. And because such testimony could have supported Defendants' claim that Turkey does not hold valid ownership over the Idol, the dearth of that testimony is prejudicial. Cf. Reif v. Nagy, 106 N.Y.S. 5, 22-23 (1st Dep't 2019) (declining to find prejudice where the lost testimony "could not have shown she had good title to the Artworks and her testimony would not have been probative."). As a result of the death of these witnesses-after Turkey should have been made aware of its claim but before it initiated this action-Turkey deprived the Defendants of the ability to seek out relevant information or testimony that would support their defenses. Such prejudice is of the kind courts have deemed relevant for laches purposes in the past. See Bakalar, 819 F. Supp. 2d at 306; see also Zuckerman, 928 F.3d at 194 ("No witnesses remain who could testify on behalf of the Met that the Sale was voluntary, or indeed on behalf of the Plaintiff that the Painting was sold 'involuntar[ily]."').

Equally notable is that, had Turkey pursued its potential claim or inquired as to the provenance of the Idol prior to 1993 , it is quite possible that Steinhardt would have never purchased the Idol. He purchased the Idol in 1993 without any claims or expressions of interest by Turkey that could put him on notice as to the potential contested nature of the Idol's ownership. Had 
Turkey inquired as to the provenance of the Idol, or argued that it held a potential claim as to the Idol, Steinhardt may not have purchased the Idol in the first place. That, too, is cognizable prejudice for purposes of laches. See Matter. of Peters $v$. Sotheby's, Inc., 821 N.Y.S. 2d 61, 68 ("the very default by the [claimants] in timely asserting their possessory rights provided legitimacy to [the buyer's] acquisition").

For the reasons stated above, the Court concludes that the Defendants have established by a preponderance of the evidence that they were prejudiced by Turkey's delay.

\section{Diligence}

In its September 30, 2019 Opinion and Order, the Court concluded that "there is no evidence in the record that Steinhardt is a bad faith possessor." Republic of Turkey v. Christie's Inc., 425 F. Supp. 3d 204, 211 (S.D.N.Y. 2019). The Court reached that conclusion because Turkey conceded that Steinhardt was not a bad faith possessor. See id. at 211. In rebutting the Defendants' laches defense, Turkey insists that even though Steinhardt is a good-faith purchaser, the Court should conclude that his purported lack of diligence weighs against a finding of laches. Turkey predicates this argument on its contention that Steinhardt was presented with sufficient red flags as to the Idol's provenance that he had acquired a duty to inquire or investigate prior to completing the purchase. The Court is unpersuaded, concluding instead that the relevant evidence in the record shows that Steinhardt was, in fact, diligent in the lead-up to the 1993 purchase of the Idol.

The Court begins with the argument that Steinhardt had a duty to investigate further after being presented with "red flags" regarding the Idol's provenance. As an ordinary purchaser, Steinhardt has no standalone duty to investigate, even if such a duty would attach to art dealers, museums, or other commercial actors. See Graffman v. Espel, No. 96 Civ. 8247 (SWK), 1998 WL 55371, at *6 (S.D.N.Y. Feb. 11, 1998) ("The Does are not art dealers and are under no obligation to adhere to commercial standards applicable to art dealers."). As in Bakalar, Steinhardt, "as an ordinary non-merchant purchaser of art, had no obligation to investigate the provenance of the Drawing, and this Court will not saddle him with a greater duty than the law requires." Bakalar, 819 F. Supp. 2 d at 306.

In any event, Turkey's claim that Steinhardt failed to inquire is contradicted by the record. The Court found Steinhardt to be a credible witness, and Steinhardt detailed the efforts he took prior to purchasing the Idol to gather more information about the history and the origins of the Idol. Steinhardt asked questions of the Merrin Gallery regarding the Idol and reviewed materials about the Idol, including a report by noted expert Prudence Harper. Tr. 614:1-12, 621:11-21 (Steinhardt); Tr. 493:7-9 (Merrin). He also met with Harper and other experts, including Carlos Picon and Joan Mertens, and consulted with people he knew were more experienced. Tr. 614:1-25 (Steinhardt); DTX 201BB ๆ
16. Indeed, while the passage of time impacted his recollection somewhat, Steinhardt "think[s] [he] spoke to a number of people at the Metropolitan Museum to try to get their understanding of this one in relation to others" (Tr. 614:1-8 (Steinhardt)), as he "had the highest regard for their expertise and ethics." DTX 201BB I 15. He also relied on the Met's good reputation (which, notwithstanding the Lydian Hoard controversy, was not unreasonable); the known provenance of the Idol (which dated back to the 1960s); and the reputation of the Guennol Collection to conclude that the Idol would not present problems. Indeed, Harper, who figures prominently in Steinhardt's recollection of the steps he took prior to purchasing the Idol, was described by $\mathrm{Dr}$. Anderson as very cautious about provenance issues. Tr. 931:3-25 (Anderson). And while Steinhardt contended that he harbored doubts as to other objects he purchased in the past, he had also testified that he had no reason to doubt the provenance of this Idol. Thus, the Court concludes that Steinhardt was reasonably diligent in inquiring as to the history and the origins of the Idol.

In sum, the Court concludes that Steinhardt's diligence was reasonable and that it certainly does not preclude Defendants' assertion of the laches defense. Having considered all elements of the laches defense, the Court concludes that the Defendants have shown by a preponderance of the evidence that Turkey knew or should have known of its claim, that it inexcusably delayed in taking action, and that the Defendants were prejudiced as a result. Thus, the Court finds in the alternative that the laches defense bars Turkey's claim.

\section{Conclusion}

For the reasons set forth above, the Court holds that Turkey did not meet its initial burden to show ownership of the Idol. Thus, Turkey's claims for replevin and conversion fail and Defendant Steinhardt is entitled to a declaratory judgment that all right, title, and interest in and to the Idol is vested in Steinhardt. The Court further concludes that even if Plaintiff met its burden of establishing ownership of the Idol under the 1906 Decree, the Defendants are entitled to judgment in their favor on their laches defense.

The Clerk of this Court is directed to enter judgment in the Defendants' favor and close the case

SO ORDERED. 